\title{
Marques ilustrando as imagens do Sofista de Platão
}

\author{
Marques illustrating the images of Plato's "Sophist"
}

\author{
Diogo Norberto Mesti
}

Resumo: O objetivo deste artigo é retomar a leitura de Marcelo Marques do conceito de imagem do Sofista de Platão, tendo como recorte o capítulo sobre a "Aporía" do livro Platão, pensador da diferença. Além de retomar essa leitura, pretende-se reconstruir as pontes sugeridas pelas epígrafes que o comentador retirou de Faulkner e de Guimarães Rosa para ilustrar o estatuto paradoxal das imagens, que são definidas no diálogo platônico como um tipo de ser que é, mas que não é aquilo que é. Com isso, pretende-se avaliar algumas imagens literarias utilizadas para falar de imagens na teoria filosófica de Platão.

Palavras-chave: Imagens; Paradoxo; Literatura, Platão; Marques

Abstract: It is intended to understand Marcelo Marques's reading of Plato's Sophist, having as subject the chapter on "Aporía" of his book Platão, pensador da diferença. We also aim to rebuild the bridges suggested by the epigraphs by Faulkner and Guimarães Rosa, which Marques used to illustrate the paradoxical status of images in the Sophist, that means, the image as a kind of being that is, but that is not what is. So, it will be possible to speak of some literary images used to speak of images in the philosophical theory of Plato.

Keywords: Images; Paradox, Literature, Plato, Marques

\section{Introdução}

Através do diálogo, o método faz com que os outros se tornem presentes, se eles não estão disponíveis pessoalmente, devem ser produzidos no discurso".

Assim como algumas obras platônicas encontraram fortuna crítica ao longo dos séculos, pode-se dizer que o Sofista tenha sido um dos diálogos de Platão mais lido no século XX. Esse diálogo procura definir a figura do sofista através de uma discussão sobre a possibilidade do falso e os laços dessa discussão com os conceitos de imagens, contrapondose à tese da impossibilidade do falso defendida pelos sofistas. Além de investigar inúmeras questões ontológicas, desde a discussão sobre os gêneros maiores: mesmo, outro, movimento e repouso, até a discussão sobre a ontologia da imagem: o que é a imagem e qual seu estatuto, esse texto também enfrenta a ontologia eleática a partir da relação entre discurso, imagem, falso e não-ser. Destaca-se que a imagem será definida como um ser que não é o que é, mas que é de certo modo, defendendo o ser do não-ser ${ }^{2}$.

\footnotetext{
${ }^{1}$ MARQUES, Platão, pensador da diferença - Uma leitura do Sofista, p. 177-178

${ }^{2}$ Para uma abordagem específica da imagem no Sofista, ver BONDESON, Sophist: falsehoods and images; ROSEN, Plato's Sophist: The Drama of Original \& Image; TEISSERENC, Remarques sur l' imitation et le statut ontologique de l' image chez Platon; MARQUES, Platão, pensador da diferença, especialmente capitulo IV "Aporía"; CRIVELLI, Plato's Account of Falsehood, em especialmente o capítulo 2 "Puzzles about not-being"; NOTOMI, The unity of Plato's Sophist, em especial capitulo 5 "Appearance and image". Para uma abordagem
}

IProfessor de Filosofia na Universidade Federal de Santa Catarina, Florianópolis, SC. E-mail: diogomesti@yahoo.com.br ORCID: https://orcid.org/oooo-0o02-5739-5627 
Os conceitos de imagem no Sofista estão em uma encruzilhada que poderia ser resumida do seguinte modo: os sofistas negam sua existência e a possibilidade de defini-la como um não-ser que é porque estão envolvidos em uma radicalização do eleatismo que já negava a possibilidade do não-ser ser, de algum modo. Na superfície, os sofistas negam a possibilidade da imagem, porém no fundo dessa negação está a defesa que eles fazem da impossibilidade de dizer o falso ${ }^{3}$. Ao tentar encontrar argumentos para se opor à interpretação sofística [da impossibilidade do falso] retirada do eleatismo [da impossibilidade do não-ser ser], Platão enfrenta uma longa discussão sobre a imagem porque nela encontramos uma das chaves da releitura do eleatismo e de sua oposição aos sofistas, já que ela dá ser [a imagem é] ao não-ser [mas não é o que é]. O objetivo do presente texto é esclarecer esse estatuto paradoxal e deslocado da imagem, de algo que é, mas não é o que é, por intermédio das epígrafes que Marques utiliza no capítulo sobre "A Aporía" da imagem em seu livro Platão, pensador da diferença. Estamos em uma duplicidade aqui, pois Marques ilustra as imagens ou usa imagens literárias para falar das filosóficas. Antes disso, a imagem merece um pouco mais de detalhe.

Podemos encontrar três grupos de intérpretes sobre o Sofista, tomando como critério o papel que eles vislumbram para as imagens. O primeiro grupo aborda a imagem de modo geral, como se ela não desempenhasse nenhum papel relevante no diálogo enquanto tal ${ }^{4}$. $\mathrm{O}$ segundo grupo ignora completamente o problema da imagem no Sofista e procura estabelecer uma ponte direta entre a aporía do não-ser e do falso com a gigantomaquia e com os gêneros maiores (movimento, repouso, mesmo e outro) ${ }^{5}$. A terceira corrente de intérpretes, com a qual nos conectamos, analisa o problema do falso a partir de sua discussão direta com as imagens, sem considerá-las como um bloco indissociável e irrelevante de aparências.

É preciso defender que não se pode saltar diretamente da aporía do não-ser e da impossibilidade do falso para a questão dos gêneros maiores, como faz o segundo grupo, sem levar em conta a estranha (atópica) solução da aporía que surge em relação a algo que é e não é simultaneamente. A imagem é a primeira solução para essa aporía e a fundação da existência da imagem é o primeiro passo para uma discussão ontológica mais consistente entre movimento, repouso, mesmo e outro. Esse artigo não pretende explicar como a aporía do não-ser é solucionada pela atopía da imagem, pois terá como foco o estatuto paradoxal

geral sobre a imagem, que menciona o Sofista, ver: VERNANT, Image et apparence dans la théorie platonicienne de la « mimesis »; DESCLOS, Idoles, icônes et phantasmes dans les dialogues de Platon.

${ }^{3}$ Esse não e nosso problema aqui, mas é preciso indicar o trabalho de Palmer (Plato's Reception of Parmenides) como exemplo dessa "encruzilhada", na qual confluem o eleatismo, a interpretação sofística do eleatismo, a impossibilidade de definição do falso e de atribuição da falsidade em relação a algo e como isso aparecerá no Sofista como alvo de Platão no centro de sua reinterpretação do eleatismo e do parricídio em relação à Parmênides. Nas palavras de Marques, esse problema aparece assim: “Ao fazer falar o Estrangeiro de Eléia, Platão está enfrentando aqueles com quem seu pensamento está em diálogo permanente, a saber, os sofistas e Parmênides, numa perspectiva socrática. Fazer falar o Estrangeiro é o modo que Platão inventa para encontrarse com Parmênides e para forçá-lo a estabelecer um diálogo dialético com ele. Nesse processo, ele recria Parmênides e o força, anacronicamente, a lidar com as implicações de seu próprio pensamento" (MARQUES, Platão, pensador da diferença, p. 45).

${ }^{4}$ Em geral, abordam a discussão do não-ser e do falso no Sofista sem detalhar como o problema da imagem e da própria diferença desempenham um papel relevante na resolução da aporía do falso. Ainda que no título desses estudos ou até mesmo em capítulos de livro apareça a noção de imagem, as imagens, suas diferenças e seus estatutos próprios são abordadas de modo geral e superficial como se não possuíssem qualquer diferença entre si. Chegaram a defender inclusive que em Platão sequer existe o conceito de imagem, como Vernant, "Image et apparence dans la théorie platonicienne de la mimesis"

${ }^{5}$ Essa perspectiva pode ser encontrada no mais recente livro de Kahn, Plato and the post-socratic dialogue. Em seu capítulo sobre o Sofista ele ignora solenemente a discussão sobre a imagem. 
da imagem e o acesso a esse estatuto pelos textos literários apresentado por Marques ${ }^{6}$.

\section{Não-ser da imagem}

O Estrangeiro apresenta no Sofista que a consequência da tese do sofista sobre a impossibilidade do falso é a negação da existência das imagens. Assim, quando o sofista defende a impossibilidade do nome, da sentença, da opinião e do pensamento serem falsos ${ }^{7}$, ele estaria negando a possibilidade mesma da existência de qualquer tipo de imagem. Esse é o motivo pelo qual o Estrangeiro concentra-se na fundação das imagens, pegando os sofistas pela consequência de seu argumento e possibilitando rever o problema originário da possibilidade do falso. Por isso é necessário definir pelo menos três vezes as imagens ao longo do diálogo, dizendo sistematicamente que as imagens são, mesmo não sendo o que é em si mesmo até que seja possível dizer também que o falso é.

O entrelaçamento entre imagem e o paradoxo do falso pode ser provado pelo próprio texto do Sofista, que diz:

Estrangeiro de Eleia: E, estando nesta aporia, uma vertigem ainda maior tomou conta de nós, quando apareceu o argumento que contradiz tudo, segundo o qual nem ícone, nem imagem, nem simulacro, nada disso é, por não haver o falso, de modo algum, jamais, em lugar algum $(264 c-d)^{8}$.

Para os sofistas, a inexistência da imagem está condicionada à inexistência do falso, de modo que o caminho escolhido para refutar os sofistas e sua tese sobre a impossibilidade do falso é provar primeiro que as imagens são de algum modo em algum lugar (como no discurso). A existência e fundação das imagens em geral são argumentos indispensáveis ao diálogo e o ponto de inflexão que levará à possibilidade de que o falso também exista em fundação da existência anterior das imagens. Não é exagero até mesmo dizer que o problema do falso no sofista depende do problema da imagem e que um não pode ser compreendido sem o outro.

Marques sustenta que o principal problema filosófico do diálogo [e do próprio enfrentamento da interpretação sofística do eleatismo] é tentar dar ser ao não-ser e é nessa esteira argumentativa que emerge a discussão sobre o estatuto das imagens, pois elas são capazes de fazer isso. Através desse tema central, Platão irá costurar inúmeros outros temas, como o combate ontológico de gigantes, a imitação, a antilogia, a linguagem e a comunicação, temas esses que serão abordados nos diversos capítulos de Platão, pensador da diferença.

No capítulo sobre a "Aporía”, Marques sustenta:

\footnotetext{
${ }^{6} \mathrm{O}$ estudo da imagem no Sofista faz parte de um projeto sobre as imagens no pensamento de Platão, que é em grande medida herdado do pensamento e dos projetos de Marcelo Marques. Tendo como foco uma leitura da República de Platão, proponho no livro Por uma diferenciação das imagens na República de Platão, o desenvolvimento de uma pesquisa que esteja mais atenta aos usos que são feitos das diversas imagens no pensamento de Platão como um todo. Algumas interpretações do Sofista que ou mencionam para desprezar ou simplesmente ignoram as imagens são derivadas de uma suposta concepção metafísica que não vislumbra nenhum papel para a imagem e para o sensível em Platão.

${ }^{7}$ Sobre isso, ver: Eutidemo, 284b1-284c6; Crátilo, 429c-430a5; República V 478b-478c; Teeteto 167a-8, 187c-20oc (especialmente 188c-189b).

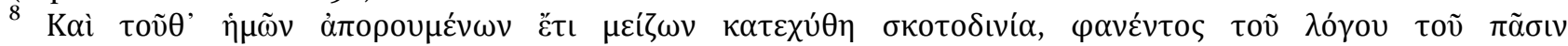

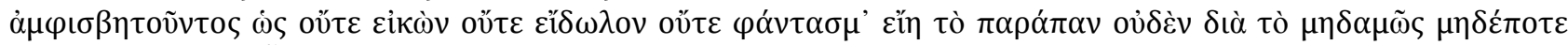
$\mu \eta \delta \alpha \mu o \tilde{v} \psi \varepsilon \varepsilon \tilde{\delta} \delta$ os عĩv $\alpha$. Destaco que utilizarei as traduções de Marques do Sofista de seu livro Platão, pensador da diferença.
} 
[...] estamos no núcleo aporético do diálogo: como fazer ser o que não é? Como a imagem pode ser, justamente sendo o que não é? Toda a questão está no "como é preciso falar". É a pesquisa sobre como encontrar esse modo de dizer que dirigirá a argumentação a partir desse ponto do diálogo. É preciso dizer o como para que se possa introduzir a necessidade naquilo que é aporético e dissolver assim o impasse. Através da sequência da argumentação, o Estrangeiro e Teeteto serão levados a considerar a hipótese de que o não-ser é, pois de outro modo o falso não poderá vir a ser algo que não é9.

$\mathrm{Na}$ sequência argumentativa, o plantonista mineiro concentra-se em explicar a relação entre a imagem e o não-ser, dizendo com todas as letras que a imagem é a solução para o paradoxo do falso e até mesmo pode ser considerada como a prova de que algo pode ser e não-ser ao mesmo tempo.

A definição da imagem como aporética e impossível serve ao interesse daquele que não quer reconhecer a autonomia ontológica da imagem ou a possibilidade do discurso falso. Enquanto aporia sem solução, esta definição é uma contradição; mas o estrangeiro tem que mostrar que ela não é uma contradição verdadeira, e para isso tem que dissolver a aporía. [...] Para ultrapassar essa perspectiva será preciso introduzir uma nova concepção de não-ser ${ }^{10}$.

"Aqueles" que não querem reconhecer o estatuto ou a autonomia ontológica da imagem são os "sofistas" acusados de defenderem que tudo em seus discursos ou em sua percepção é sempre verdadeiro e nada poderia ser considerado como falso. Por trás da defesa dos sofistas da impossibilidade do falso encontra-se a tese de que tudo é sempre verdadeiro. Mesmo levando em conta essas dimensões, o diálogo não esgota todas e concentra-se na relação entre imagem e não-ser para conseguir fundar a própria linguagem e a diferenciação entre discursos verdadeiros e falsos. Marques sustenta que a utilização da imagem como solução para o problema do não-ser está ligada ao problema mesmo da alteridade no pensamento de Platão. A imagem seria um não-ser que é de certo modo, outra coisa que o ser, mas que não poderia ser enquadrada em uma espécie de não-ser absoluto. $\mathrm{O}$ autor defende que é "preciso mostrar que alguma coisa não é a mesma", "deve-se mostrar que há diferença onde se acreditava que só havia identidade”, buscando encontrar um nãoser "que não é, em certo sentido, e de um certo modo, ou seja, um não-ser relativo" .

\subsection{Ilustrando as imagens: não-ser na literatura}

A intenção até aqui foi apresentar a imagem como a principal encruzilhada no Sofista porque é nela que o Estrangeiro (eleata de origem) precisa enfrentar ao mesmo tempo o eleatismo e a interpretação sofística do eleatismo. Isso acontece porque ele defenderá a possibilidade da imagem ser um não-ser que é e com isso redefine a tese da impossibilidade do falso defendida pelos sofistas. Feito isso, podemos agora tomar um desvio e seguir pelas epígrafes que Marcelo Marques utiliza para dizer aquilo que não é explicitado sobre esse estatuto paradoxal das imagens.

Marques utiliza alguns textos literários como epígrafes ao longo de todo o livro Platão, pensador da diferença. A primeira epígrafe é uma utilizada por Borges de Bacon no

\footnotetext{
${ }^{9}$ MARQUES, Platão, pensador da diferença, p. 156

${ }^{10}$ Idem, p. 171

${ }^{11}$ Idem, p. 172
} 
conto O imortal: "Solomon saith: "There is no new thing upon earth". So that as Plato had an imagination, "that knowledge was but remembrance"; so Solomon giveth sentence, "that all novelty is but oblivion”. A última epígrafe de seu livro é de Guimarães Rosa, de Tutaméia: “o livro pode valer pelo muito que nele não deve caber”. Em certa medida, suas epígrafes são inspiradoras ou tentam apontar para aquilo que não coube no livro e para aquilo que nele aparece de novo, mas que na verdade pode ser somente algum tipo esquecimento. São epígrafes que indicam um limite mesmo das imagens e que tornam a filosofia limitada se comparada ao que a imagem e a literatura conseguem fazer.

O comentador tem uma predileção pela literatura "modernista". Ele cita 4 vezes Borges, 5 vezes Rosa e 1 vez Faulkner. No momento em que ele fala das imagens, o uso dessas epígrafes ganha um sentido especial, pois todos os trechos lidam com o estranhamento presente na definição da imagem como algo que estaria na fronteira entre ser e não-ser. Ele não extrai e nem conecta sua reflexão diretamente aos trechos literários citados, que permanecem como indicadores intocados para conexões que o autor vê, mas que não detalha. As epígrafes são em certa medida aquilo que transborda e nossa tentativa é seguir por isso que transbordou: esse ser que não é, mas que é, que não está no texto, mas que está com o texto, como uma estranha mediação inerente a todos os tipos de imagens. Em outros termos, as estranhas imagens [escolhidas por Marques] para falar da estranheza mesma das imagens. É uma espécie de analogia hermenêutica em aberto, como uma ponte a ser construída nesse espaço atópico das imagens, do próprio discurso filosófico e daquilo que a literatura atinge quando faz o sentido transbordar e deixa a interpretação em aberto. O que está em jogo aqui é refletir sobre o estatuto ontológico das imagens e sobre a possibilidade de vislumbrar nas imagens construídas pela literatura um tipo de discurso até mesmo mais "claro" do que a própria filosofia.

\subsubsection{Darl de "Enquanto agonizo"}

O primeiro trecho citado no capítulo “Aporía” de Marques é uma fala de Darl retirado do livro de William Faulkner (1897-1962) Enquanto agonizo (As I Lay Dying), que foi escrito em 1930. O livro retrata 59 monólogos de 15 narradores, mostrando as diversas perspectivas dos membros da família Brunden e das pessoas com quem eles cruzam enquanto estão no trajeto de 40 quilômetros para cumprirem a promessa de enterrar a matriarca da família, Addie Bundren, junto ao restante de seus familiares.

Essa diversidade de perspectivas muitas vezes incoerentes entre si, reunidas em partes que nem sempre possuem sentido faz parte do estilo modernista de Faulkner e implica uma ruptura com as grandes coerências narrativas que marcaram a história da literatura. Ele retrata as incoerências oriundas da fragmentação e multiplicidade discursiva ${ }^{12}$ e, nessa fragmentação, os monólogos do filho de Addie Bundren, Darl, se destacam pelos traços eminentemente paradoxais e contraditórios de suas experiências e reflexões.

Dentre as falas de Darl, temos duas em especial que se destacam. Elas abordam temas complexos como as relações entre espaço e tempo ${ }^{13}$ e sobre as transições entre sono e vigília.

\footnotetext{
${ }^{12}$ Como destacam as autoras Barros e Brito, retomando um poeta irlândes Yeats, "está-se diante de um movimento do histórico em que se perde tanto a coerência quanto a possibilidade de entendimento do mundo" (apud BARROS e BRITO, Darl, o homem de gênio em Faulkner, p. 10).

${ }^{13}$ A passagem sobre o tempo merece ser citada aqui. Ela ocorre quando eles precisam atravessar um longo trecho do rio: "O rio, por si mesmo, não tem mais de cem metros de largura, e Pai e Vernon e Vardaman e Dewey Dell são as únicas coisas à vista, sem falar na monotonia singular daquela desolação que parece estender-se, terrível, da direita para a esquerda, como se tivéssemos atingido o lugar onde o movimento do mundo devastado se acelera, pouco antes do precipício final. Contudo, eles parecem encolhidos. Como se o espaço entre nós fosse só tempo: uma coisa irrevogável, como se o tempo já não corresse diretamente à nossa
} 
A passagem citada por Marques diz respeito ao segundo tema, sobre sono e vigília, que se envolve em um pêndulo entre ser e não-ser, estar e não-estar. Esse trecho joga com a possibilidade ou a impossibilidade de se saber com exatidão as temporalidades ${ }^{14}$ que estão envolvidas na definição de ser aquilo que é ou não é ou que nunca foi. Deve-se destacar que não há linearidade temporal nas falas de Darl, não há um antes e um depois e um presente, mas a simultaneidade de passado, presente e futuro. Parece se manifestar aqui uma estrutura de continuidade no tempo que se alastra pelo espaço, de modo que assim como haveria certa arbitrariedade ou convenção na marcação do tempo $1,2,3,4$, talvez haveria arbitrariedade nas marcações espaciais.

Essa fala de Darl acontece em um momento em que seus irmãos terminaram de construir o caixão para sua mãe e ele passa a refletir sobre o sono ou refletir no sono colocando-se no limiar entre vida e morte, existência e inexistência, permanência e mudança. No trecho em questão do livro há uma dissociação socrática, digamos assim, na oposição entre saber que não sabe (Darl) e não saber que não sabe (Jewell). Darl sabe que não sabe o que ele mesmo é, diferentemente de seu irmão Jewell "que [acha que] sabe o que ele é" porque não sabe que ele não sabe. A possibilidade de adormecer ocorre pelo saber que não é, e isso permitiria Darl esvaziar-se para dormir, que é quando "você não é"; enquanto seu irmão Jewell não pode se esvaziar para dormir "porque ele não é o que ele é e é o que não é".

Somente Darl é capaz de se esvaziar em determinado quarto estranho antes de dormir, deixando de ser, enquanto ele está esvaziado para dormir, até nunca ter sido, quando se está cheio de sono.

Darl - Num quarto estranho, você tem que se esvaziar para dormir. E antes de estar esvaziado para dormir, o que é você? E quando você está esvaziado para dormir, você não é. E quando você está cheio de sono, você nunca foi. Eu não sei o que sou. Eu não sei se eu sou ou não. Jewell sabe que ele é, porque ele não sabe que ele não sabe se ele é ou não. Ele não pode se esvaziar para dormir, porque ele não é o que ele é e é o que ele não é ${ }^{15,16}$.

Esse recorte feito por Marques deixa esse trecho mais abstrato do que ele efetivamente é no texto de Faulkner. Reconstruindo o contexto e a continuação do

frente, em linha decrescente, mas se escoasse, paralelo, entre nós, qual corda dobrada, e a distância fossem as dobras, não o intervalo entre elas. As mulas param, com os quartos dianteiros já um pouco inclinados e as ancas elevadas. Também elas respiram agora com profundo som enrouquecido, olham uma vez para trás, roçando em nós seus olhos selvagens, tristes, profundos e desesperançados, como se já tivessem visto na água grossa a imagem do desastre de que não podem falar e que não podemos ver" (FAULKNER, Enquanto Agonizo, p. 65).

${ }^{14}$ Sobre a temporalidade de Faulkner, Barros e Brito começam adotando uma frase escrita por Sartre sobre Faulkner: "De acordo com Jean-Paul Sartre, 'nas obras de Faulkner, não há progressão alguma, não há nada que venha do futuro" (Darl, o homem de gênio em Faulkner, p. 87-93), por isso também a necessidade de se destruir a cronologia dos eventos e ação do tempo passar a ser psicológica. É verdade que o passado às vezes invade intuitivamente a narrativa por meio do fluxo de consciência, mas é o tempo presente que perdura, como se Faulkner o tivesse congelado para então poder ver a essência das coisas. Vale lembrar, ainda, que esse tempoespaço imóvel a que estão submetidas suas personagens está estritamente conectado à imobilidade do contexto da região sulista da que elas e o autor fazem parte" (Darl, o homem de gênio em Faulkner, p. 17).

${ }^{15}$ FAULKNER, apud, MARQUES, Platão, pensador da diferença, p. 155

${ }^{16}$ A tradução acima é, aparentemente, de Marques. A de Hélio Pólvora é a seguinte: "Em quarto estranho é preciso criar em nós mesmos o vazio, para poder dormir. E antes de se ficar vazio para o sono: que é que somos, afinal? E quando ficamos vazios para o sono, já não somos nada. E quando estamos cheios de sono nunca somos nada. Não sei o que sou. Não sei se sou ou não sou. Jewel sabe que ele é, porque não sabe que ele não sabe se é ou não é. Não pode esvaziar-se para dormir porque não é o que é e é o que não é" (FAULKNER, Enquanto Agonizo, p. 38). 
monólogo, podemos dizer que o problema fica mais claro e menos enigmático, inclusive do ponto de vista afirmativo sobre o não ser. Darl descreve a chuva modelando a carroça, que não é da família, e sua carga de madeira para o caixão, que não é mais de quem a serrou, nem de quem construirá o caixão, mas da mãe. Nesse momento, o sono é o não ser e isso auxilia a compreender o que Darl apresenta nessas transições entre estar acordado (sabendo que não se sabe se é ou não é ou não sabendo que não se sabe se é ou não é) e estar dormindo, que seria o não ser efetivo.

E já que o sono é o não ser e a chuva e o vento são o que foram, a carroça não é. Contudo, a carroça é, porque quando a carroça era Addie Bundren não seria. E Jewell é, portanto Addie Bundren tem de ser. E, nesse caso, eu devo ser, ou não poderia esvaziar-me para dormir em quarto estranho, e se ainda não estou vazio, então sou. Quantas vezes já dormi embaixo da chuva, em teto estranho, pensando na minha casa $^{17}$.

Jewell é dez anos mais novo do que Darl e é segundo insinuações que se espalham no texto filho de um caso que a mãe deles teve com outro homem para se vingar do marido. A interpretação desse trecho depende dessa relação conflituosa entre eles e da dependência existencial de todos da própria matriarca. "O sono é o não ser" marca uma espécie de esvaziamento que permite o afastamento do ser e reencontro com o não-ser. Ao se encontrar esvaziado, não somos e quando estamos nos esvaziando ou "estamos cheio de sono", nunca fomos. Jewell não pode se esvaziar para dormir porque ele sabe que ele é, o que pode implicar estar em um estado de vigília constante mas marcado por uma ignorância que é não saber que não sabe. A impossibilidade dele se esvaziar para dormir ocorre em razão desse saber indeterminado, desse não saber que não sabe se é ou não, enquanto a possibilidade de se esvaziar presente em Darl implica em saber que não sabe se ele é ou não é.

Depois daquela primeira parte mais ontológica, que é escolhida por Marques para representar os paradoxos envolvidos na aporia da imagem, Darl continua o monólogo retomando coisas concretas que estão ao seu redor, como a carroça, sua mãe, seu irmão e a chuva. E conclui que ele "deve" ser porque do contrário não poderia se esvaziar e como ainda não se esvaziou, então ele ainda é. Logo no início desse capítulo Marques dirá: "Aporia significa impasse e é justamente da impossibilidade que se gera a exigência de passagem, fazendo com que avancem na pesquisa"18, o que não deixa de ter relação com a passagem de cada um dos personagens do livro de Faulkner. Todos possuem algum interesse secundário privado em levar o caixão da matriarca da família até a cidade de Jefferson. $O$ pai originalmente impelido em cumprir sua promessa deseja na verdade uma dentadura nova. Chegando em Jefferson, ele vende o cavalo que é a paixão de Jewell e rouba o dinheiro da filha Dewey, pois havia utilizado o dinheiro da dentadura nova para comprar outros cavalos no meio do trajeto. A garota Dewey queria apenas ir à cidade para conseguir um abortivo e Cash, o filho mais velho, economizou dinheiro para comprar um novo gramofone.

Como apontam Barros e Brito, Darl é visto pela vizinha da família, a religiosa Cora, como o único que possuiria algum sentimento e que foi capaz de amar a própria mãe, mesmo não tendo sido o preferido dela, ao mesmo tempo em que era considerado pelos outros como estranho, preguiçoso, sempre vagando por aí, aporético! Contudo, o marido da vizinha Cora, Tull, um defensor do homem comum trabalhador, olhava para Darl como alguém cujo principal problema era pensar demais, dado o caráter permanentemente

\footnotetext{
${ }^{17}$ FAULKNER, Enquanto Agonizo, p. 38

${ }^{18}$ MARQUES, Platão, pensador da diferença, p. 155
} 
contemplativo de Darl percebido na fixação de seu olhar para a terra ou para as pessoas ${ }^{19}$. $\mathrm{O}$ comportamento estranho de Darl incomoda a todos durante a viagem e ele acaba sendo internado em um hospital psiquiátrico pela família por ter ateado fogo no celeiro em que o cadáver de sua mãe estava enquanto todos os membros da família descansavam longe do cheiro mórbido. Darl tentou encerrar com esse ato o problema de todos, incinerando o corpo putrefato de sua mãe. Justamente por esse incêndio os donos do celeiro movem uma ação judicial e a família declara que Darl é insano e o internam em uma instituição mental em Jackson.

\subsubsection{Provérbio árabe}

A segunda epígrafe do capítulo "Aporía” é um Provérbio Árabe: "Precisamos da miragem para sermos capazes de atravessar o deserto" ${ }^{20}$, que aparece no subitem do capítulo intitulado "A aporia da imagem". A miragem deve ser compreendida como um efeito óptico que acontece nos horários mais quentes do dia no deserto. Ela é resultado do calor conjugado a um reflexo projetado pela luz do sol, criando uma imagem de algum lago no qual podem ter imagens de outras coisas desejadas também, exatamente como em um sonho que acontece com as pessoas acordadas.

Essa miragem necessária para a travessia do deserto é uma referência direta ao papel da imagem como possível solução para a aporía sobre o falso do diálogo. A solução para a aporía desértica da impossibilidade do falso, criada pelos Sofistas, está na reconstrução daquilo que eles procuram negar, a saber, a existência da imagem, que funcionará então como miragem e travessia para a possibilidade de encontrarmos a possibilidade do falso e com isso refutar a tese dos sofistas. Nesse sentido, precisamos de uma definição para as imagens e a consolidação de sua existência para atravessar o deserto aporético da impossibilidade do falso. As imagens e sua fundação ontológica na transição entre ser e nãoser, pois elas não são, mas são de algum modo, servem para construir a possibilidade de passagem ou de saída da aporia que também abrirá as portas para uma revisão do eleatismo radicalizado dos sofistas.

O problema do falso pode ser considerado como uma verdadeira encruzilhada, como já dissemos, por onde passam inúmeras teorias de Platão, envolvendo a linguagem, a ontologia, a política, a educação e os prazeres. No caso do Sofista, os dois principais caminhos que nos levam ou que saem dessa encruzilhada são o da linguagem, fundado na pergunta: como dizer o não-ser? E o da ontologia: como o não-ser pode ser? Ignorar a possibilidade de que a imagem funcione como uma solução estranha para o problema discursivo e ontológico do falso pode implicar que o deserto (da ontologia ou da filosofia) sem miragens (sem linguagem) não possa ser superado e percorrido. A imagem (e a miragem) são soluções provisórias para o problema. Ignorar as imagens ou considerá-las confusas e obscuras implica em não se mover. Há um estranho caminho de saída para o problema do falso justamente através daquilo que parece ser o maior motivo de engano: as imagens ou miragens necessárias para a própria filosofia.

\footnotetext{
${ }^{19}$ Em determinado momento, Darl é descrito pelo próprio pai como alguém que tem olhos para a terra o tempo todo. Anse diz: "E Darl? Todos querendo afastá-lo de mim, malditos sejam. Não é que eu receie o trabalho; sempre ganhei o sustento para mim e os de casa e nunca nos faltou um teto: o problema é que queriam tirarme Darl só porque ele sabe onde tem o nariz, só porque ele vive a pensar na plantação. Eu lhes disse: ele ia bem, a princípio, com os olhos postos na terra, porque a terra se estendia para cima e para baixo; foi quando essa estrada apareceu e dividiu e encompridou a terra, e como os olhos de Darl continuassem postos na terra, então eles começaram a ameaçar-me de tirá-lo de mim, com a ajuda da lei" (FAULKNER, Enquanto Agonizo, p. 21).

${ }^{20}$ Apud, MARQUES, Platão, pensador da diferença, p. 167
} 


\subsubsection{Carta VII de Platão}

A terceira epígrafe é platônica e aparece no subitem "As aporias do ser": "Pois é ao mesmo tempo que se deve aprender o verdadeiro e o falso sobre o ser, em sua totalidade, após ter consagrado a esta tarefa todos os seus cuidados e muito tempo, como eu dizia no início"21 (Carta VII 344b1-3). Essa carta de Platão, sem entrar na vasta discussão sobre sua autenticidade, apresenta seu envolvimento político em Siracusa, para onde ele teria ido mas onde ele acabou ficando preso. Passa pela sua vontade inicial de participar da política, pelo que aconteceu com Sócrates quando se recusou a se envolver com governo dos Trinta e inúmeros outros aspectos da relação entre filosofia e política.

O trecho citado, porém, faz parte de uma digressão epistemológica da carta, onde Platão começa a detalhar a ligação e o interesse de Dionísio com a filosofia (340a ss.). Nesse trecho ele apresenta os elementos constituintes do saber que sintetizam alguns aspectos de suas discussões filosóficas, ao dizer que existem quatro elementos importantes no conhecimento de algo (342a-343a): o nome, a definição (lógos), a imagem e a ciência, que são a porta de entrada para a possibilidade do entendimento. Os exemplos que ele utiliza são: o nome, a definição, a imagem e a ciência do círculo, expandindo isso para figuras retilíneas e também para os valores (como o bem, o belo e o justo). Destaca-se também a possibilidade de múltiplos caminhos que podem ser tomados, na medida em que ter um desses elementos implica que devemos buscar os outros e assim ter uma visão ampla da essência.

Essa é a base para a citação em questão. O trecho escolhido por Marques antecipa uma definição de dialética que a segue e que frequentemente era citada por ele em sala quando defendia que a dialética é uma espécie de friç̧ão contínua entre aqueles diversos elementos apresentados acima. Ao que aparece "como eu dizia no início" tem o seguinte desdobramento:

Só depois de esfregarmos, por assim dizer, uns nos outros, e compararmos nomes, definições, visões, sensações e de discuti-los nesses colóquios amistosos em que perguntas e respostas se formulam sem o menor ressaibo de inveja, é que brilham sobre cada objeto a sabedoria e o entendimento com a tensão máxima de que for capaz a inteligência humana ${ }^{22}$ (Carta VII 344b-c).

Aquela epígrafe dialoga com a tese sofística que chegava a defender que tudo que é só pode ser automaticamente verdadeiro. Assim, a simultaneidade entre verdadeiro e falso implica a possibilidade de se defender que existem opiniões, ou juízos ou argumentos que podem estar errados e serem falsos quando os nomes, as definições, as impressões e a reflexão epistêmica sobre os seres são confrontados entre si. Além do elemento incontornável da linguagem para compreensão dos seres, aqui aparece também uma espécie de ruptura com as divisões temporais entre ser e não-ser, como na tese do tipo: é, e não pode nunca não-ser. Nesse trecho, depois de apresentar a imagem, Marques passará a discutir que a imagem representa o elemento linguístico que é constitutivo do pensamento, quando afirma: "para atravessar o páthos da aporia, os interlocutores têm que se submeter a um certo modo de dialogar, ao caminho dialético, o único que permite que o logos

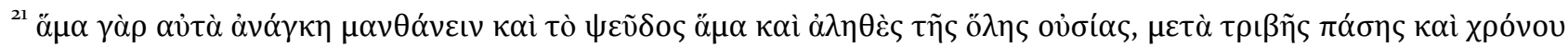

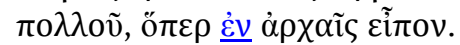

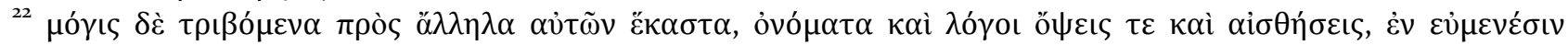

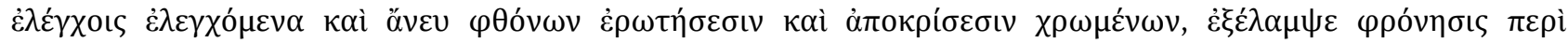

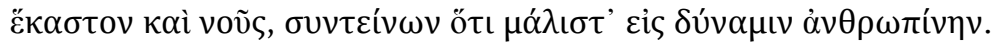


verdadeiro se mostre, de um aporia à outra como um caminho que persiste"23. A simultaneidade da verdade e da falsidade é também a simultaneidade entre imagem e aquilo de que a imagem é imagem ou uma simultaneidade entre o ser da imagem que é, mas não é o que é. Essa simultaneidade se apresenta no diálogo platônico Sofista por meio da noção de entrelaçamento (symploké), imediatamente depois de tentar definir o ícone como algo que realmente é:

Teeteto: pode ser que tal ligação (symplokén) entrelace o não-ser ao ser e ela é muito estranha. Estrangeiro: Pois como não seria estranha? Pelo menos, tu vês, agora, graças a este entrelaçamento, que o sofista de múltiplas cabeças nos forçou a concordar, contra nós mesmos, que o não-ser é, de algum modo. Teeteto: eu vejo, e muito bem (240c).

Esse entrelaçamento do não-ser com o ser ocorre pela imagem, que passa a impedir que o não-ser implique diretamente uma não existência. Assim, não é apenas o sentido positivo: é, que terá valor absoluto, pois o uso negativo do verbo ser: não é, pode também ser de algum modo pensado e dito, ainda que estranhamente. Glosando Teeteto, "podemos ver, e muito bem", essa estranha reunião de verdade e falsidade.

\subsubsection{A terceira margem do rio de Rosa}

A última epígrafe do capítulo "Aporía" é do conto A terceira margem do rio de Rosa e aparece no subitem “A krísis do Estrangeiro”. É pertinente destacar que como Faulkner, Rosa também pertence ao movimento de escritores considerados modernos. A obra icônica de Guimarães Rosa, Grande Sertão: Veredas, teve grande fortuna crítica pela desconstrução original da linguagem e pela recriação fantástica de uma linguagem do sertão que não é apenas uma linguagem regional, mas universal. Mas não é somente essa obra de Rosa que merece destaque.

Dentre seus contos, A terceira margem do rio está em um livro intitulado Primeiras estórias, que tematiza inúmeros momentos da vida, envolvendo-se em uma discussão "sobre a infância, a loucura e a passagem abrupta de um estado de normalidade para o absurdo, sem explicações ou o destaque de causas" ${ }^{24}$. A história é narrada por um dos filhos de um homem que decide construir um barco e nele ficar pelo resto de sua vida, sem voltar para casa. O filho permanece nesse monólogo sem saber os motivos do pai, tentando ajudá-lo ao ponto de questionar sua própria sanidade quando toda a família vai embora e só ele permanece ainda buscando reencontrar-se com seu pai. $\mathrm{O}$ reencontro com o pai nunca acontece por causa da situação estranha em que o pai se encontra.

No A terceira margem do rio, o pai do narrador vive essa transposição para um local indeterminado, para um não local, que enquanto tal é a marca da ausência de lugar ( $a$ privativo em grego + topos) da imagem. De pai cumpridor, ordeiro e positivo, ele se transforma em algo difícil de compreender quando decide passar o resto da vida boiando no meio do rio, sem ir embora, sem voltar, sem explicar. O trecho escolhido por Marques retrata essas questões colocadas pelo filho ainda jovem, quando o pai decide ir para o rio.

"Pai, o senhor me leva junto nessa sua canoa?" Ele só retornou o olhar em mim e me botou a benção, com gesto me mandando para trás. Fiz que vim, mas ainda virei, na grota do mato, para saber. Nosso pai entrou na canoa e desamarrou, pelo remar. E a

\footnotetext{
${ }^{23}$ MARQUES, Platão, pensador da diferença, p. 174

${ }^{24}$ ARAÚJO, A poética moderna em “A terceira margem do rio”, de João Guimarães Rosa, p. 367 
canoa saiu se indo - a sombra dele por igual feito um jacaré, comprida longa. Nosso pai não voltou. Ele não tinha ido a nenhuma parte ${ }^{25}$.

O filho permanece ao redor do pai por uma espécie de culpa que se transforma em angústia e que o imobilizou durante toda a vida ${ }^{26}$. Não são apenas os motivos do pai que são enigmáticos, a sua existência ou localização também é enigmática. Por isso, o que significa esse deslocamento do pai? Será que ele estaria em algum lugar especial que transcende todos os outros lugares? Esse lugar transcendente, por exemplo, seria uma espécie de misantropia social onde haveria alguma forma de entendimento puro? Ou o que está em jogo é uma impossibilidade de resolver a contradição ou o paradoxo, sendo necessário interpretar esse deslocamento como estar e não-estar ao mesmo tempo em algum lugar? Como uma espécie de presença ausente?

Marques aponta em seu texto para a opção do deslocamento e para uma presença ausente quando se refere nesse momento à capacidade da dialética de recriar o interlocutor, sustentando-se pela sua capacidade de "pensar radicalmente a alteridade", estabelecendo "um diálogo crítico com os outros 'como se eles mesmos estivessem presentes' (hoîon houton paronton)" 27 .

O texto de Rosa parece indicar também a alternativa de uma ausência presente, conectada à impossibilidade de determinação do lugar que alguém pode ocupar sob o rio sem estar ancorado nas margens. Estar sob o rio, em um barco, é como estar sob o fluxo que transita pela simultaneidade de algo que é (presente) e não é (ausente) ao mesmo tempo, como o filho sentindo-se culpado: "Sou homem de triste palavras. De que era que eu tinha tanta, tanta culpa? Se o meu pai, sempre fazendo ausência: e o rio-rio-rio, o rio - pondo perpétuo" 28 .

Durante todo o conto, o filho se indaga porque afinal o pai não foi embora, não desamarrou os laços dessa terceira margem em que ele se ancorou e deixou o barco seguir pelo rio, tendo escolhido ficar "na vagação, no rio no ermo". O pai decide isolar-se de todos, mas esse isolamento mesmo não ocorre em um lugar fixo em que ele possa ser encontrado ou até mesmo em outro lugar absolutamente distante. O lugar escolhido pelo pai é errático, fortemente indeterminado. Em outro momento, o filho chama o pai para trocar de lugar com ele e, na imaginação monológica do filho, o pai vai se aproximando como se estivesse cansado e disposto a trocar de lugar, mas o filho foge.

Depois de fugir, ele repensa sua relação com o rio. Ao contrário do pai, que permanece fixo sob a mudança do fluxo, marcada pela repetição do mesmo rio em "rio-riorio, o rio - pondo perpétuo", onde ele permanece ausente: "sempre fazendo ausência", o filho tenta estabelecer outra relação imaginária com o rio. O próprio filho também havia se isolado de todos e aceita que quando morrer até poderiam colocá-lo "numa canoinha de nada, nessa água que não para, de longas beiras: e, eu, rio abaixo, rio a fora, rio a dentro - o rio" ${ }^{29}$. No primeiro caso, o rio-rio-rio do pai se contrapõe à água que não para do rio abaixo, rio a fora, rio a dentro do filho quando morrer. Curiosamente, morrer é fluir. Se o pai tivesse

\footnotetext{
${ }^{25}$ ROSA, A terceira margem do rio, p. 78

${ }^{26}$ Como indica Melo, ao sustentar que: "Em A terceira margem do rio, a angústia se configura como uma mescla de desejo de vida (a fuga) e desejo de morte (o pedido). No entanto, o filho-narrador não assume nem uma coisa nem outra. Ele não dá conta de ser para-si nem para-o-outro (o pai). Daí o fato de permanecer no entrelugar. Esta situação é que o imobiliza inexoravelmente em face da existência” (MELO, A questão da ambivalência em "A terceira margem do rio", p. 115).

${ }^{27}$ MARQUES, Platão, pensador da diferença, p. 177

${ }^{28}$ ROSA, A terceira margem do rio, p. 81

${ }^{29}$ ROSA, A terceira margem do rio, p. 82
} 
deixado a canoa fluir pelo rio indo para algum outro lugar, indo definitivamente embora, talvez ele tivesse morrido e libertado o filho ${ }^{30}$.

A terceira margem de um rio é criada arbitrariamente pela insistência do pai em permanecer sob pontos escondidos do rio que fluem e criam uma terceira margem que é a dele mesmo ancorado ou circulando no meio ou nos cantos escondidos do rio. Ele força com isso uma permanência sob o fluxo do rio, um lugar sem lugar, uma atopía. Diante disso, todos aqueles que ancoram em algum lugar na água criam uma espécie de terceira margem, na medida em que criam algo fixo que não se move, como as margens, no meio daquilo que sempre está se movendo. A terceira margem é um não-lugar porque para e repousa sobre o que não está parado. Pode-se dizer também que a terceira margem é uma espécie de ilha, que é construída no meio do mar e que diferente das margens terrestres que limitam o rio possui como margem a própria água. Assim, a ilha ou a canoa são uma espécie de terceira margem. É como uma vida vivida em silêncio, ilhada, de alguém que está ao seu lado mas que não fala ${ }^{31}$. O rio é a estrutura do conto e enquanto tal ele não permite que as contradições ou oposições de ser ou não ser, de estar ou não estar, de ir ou ficar, se resolvam ou se decidam ${ }^{32}$.

Não há, no final, nenhuma explicação para os motivos do pai, sendo possível apenas compreender ou mais do que compreender aceitar essa impossibilidade de determinar o ocorrido $^{33}$. Como indica Araújo, nenhuma das soluções que propõe o lugar do pai como uma espécie de lugar transcendente e determinado dá conta do absurdo, do conflito ou da aporía sem resolução que é alguém que vai, mas não vai. Como a arte moderna, o texto de Rosa leva em conta sobretudo a indeterminação que recusa inevitavelmente a transcendência ${ }^{34}$.

\footnotetext{
${ }^{30}$ Como indica Melo, o rio aparece desde o início do conto, sendo concebido como próximo à casa e possuindo a mesma qualidade que marca a vida inteira do pai. O silêncio paterno é o silêncio do rio: "Nossa casa, no tempo, ainda era mais próxima do rio, obra de nem quarto de légua: o rio por aí se estendendo grande, fundo, calado que sempre. Largo, de não se poder ver a forma da outra beira". O rio chega a ser uma espécie de imagem do que o homem é. O silêncio dele não é causado por sua retirada para lugar algum, mas ele se retira por causa do silêncio inerente a ele que se espelha também no rio sempre calado. (MELO, A questão da ambivalência em "A terceira margem do rio", p. 120-121).

${ }^{31}$ Melo, retomando Galvão, defende que o "rio teria duas margens que são e uma terceira que não é. Esta última seria o mistério, o desconhecido, o insondável, o indizível. Veja-se que o pai, ao fazer a transição do mundo real, do logos, do pragmatismo para o mundo do mistério, ou seja, do mundo da terra (esta, metáfora do real) para o mundo da água (esta, metáfora do onírico, do irreal), nunca mais fala." (MELO, A questão da ambivalência em "A terceira margem do rio", p. 111-112).

${ }^{32}$ É muito clara a posição de Rónai a esse respeito, retomada por Melo: há uma "primazia da 'antonímia metafísica', figura estilística que "surge em palavras que não indicam manifestação do real e sim abstrações opostas a fenômenos percebíveis pelos sentidos". O tropo dá-se à luz em palavras como desalegria, desverde, indestruir ou acronologia, entre outras, que no contexto em que aparecem "indicam algo mais do que a simples negação do antônimo: aludem a uma nova modalidade de ser ou de agir, a manifestação positiva do que não é" (Apud MELO, A questão da ambivalência em "A terceira margem do rio", p. 117).

${ }_{33}$ Como destaca Melo, nesse mesmo sentido: "Ele não se assume como filho porque não consegue assumir o pai: metáfora da origem. Ao permanecer à beira do rio à espera do regresso do pai e, consequentemente, preso a ele, o filho talvez queira decifrar o indecifrável. Ou senão espera dele a explicação de sua estranha fuga. $\mathrm{O}$ grande drama do filho é o não-entendimento desta 'doideira' do pai. É ela que o desestrutura irremediavelmente. Sua hesitação, sua falta de definição, sua situação de entrelugar e, por conseguinte, a destruição de si mesmo são resultantes de sua impossibilidade de superar o pai e o tempo" (MELO, A questão da ambivalência em "A terceira margem do rio", p. 121).

${ }^{34}$ Concordamos com a falta de transcendência em jogo, conforme a perspectiva adotada por Burgos: "É nesse contexto que podemos entender a dificuldade de aceitar que a ação do pai em A terceira margem do rio fique irresoluta como sujeito de uma interpretação, ou melhor, que se apresente como a instalação de um enigma para o qual não se oferecem perceptíveis claves narrativas ou cuja existência haja sido complicadamente codificada na exuberância de signos transformados em imagens e da ulterior conversão destas em gestações
} 
A racionalização na verdade é impossível diante desse horizonte paradoxal de um pai que decide não viver sem se suicidar; se mover sem se deslocar; ir mas ficar. Nos termos do conto isso aparece como: "ele não tinha ido a nenhuma parte" e "aquilo que não havia, acontecia" ou na fala da mãe: "Cê vai, ocê fique, você nunca volte!"35. E isso é concebido pelo filho narrador como estranho: "A estranheza dessa verdade deu para estarrecer de todo a gente. Aquilo que não havia, acontecia" ${ }^{36}$. Aceita-se com certa normalidade essa estranheza. Em outras palavras a frase "aquilo que não havia, acontecia" pode ser traduzida como aquilo que não é, mas estava sendo naquele momento ou aquilo que não existia, mas passava a existir. Essa frase encerra o parágrafo que inicia com: "nosso pai não voltou. Ele não tinha ido a nenhuma parte". Esses elementos são cruciais para se contrapor a uma leitura metafísica, mística ou até sociológica do deslocamento do pai que fica no meio do rio ${ }^{37}$.

A mesma loucura que pode ser percebida em Darl e também naquele que vislumbra a miragem como útil para a passagem aparece aqui em relação ao observador da junção da ausência presente do pai. $\mathrm{O}$ narrador chega ao ponto de aceitar uma espécie de universalização da loucura. Quando já velho, fica preocupado com o pai que não deixa soltar a canoa para acabar logo com aquilo na cachoeira. O filho se pergunta: "Sou doido? Não. Na nossa casa, a palavra doido não se falava, nunca mais se falou, os anos todos, não se condenava ninguém de doido. Ninguém é doido. Ou, então, todos"38.

Enquanto a passagem acima da Carta VII mostra uma simultaneidade e até mesmo uma certa reciprocidade de opostos, a passagem de Rosa apresenta uma simultaneidade de estar e não-estar ou entre presença e ausência que já havia aparecido no primeiro trecho citado de Darl e também no segundo trecho da miragem. Essa dualidade (e o próximo subitem do capítulo sobre a Aporía na obra de Marcelo será também sobre a "A aporia da dualidade" [p. 181]) gera o mesmo tipo de estranhamento ou atopía que a imagem gera como uma solução que não é definitiva, mas estranha, para o problema da aporía do falso. Além disso, isso pode nos levar à visão de que esses opostos sejam tratados por uma certa reciprocidade. Por enquanto, podemos dizer que o barco é a imagem que paira em um estranho lugar no fluxo da linguagem; o barco é a miragem; o barco é a loucura.

Há um elemento subjacente em toda essa discussão que não foi destacado até o momento. Trata-se da força dialética entre movimento e repouso, que se apresenta como problema subsequente à discussão sobre a aporía da imagem no Sofista. Como dito acima, o debate ontológico específico apresentado no Sofista fica mais claro depois de compreender a aporia da imagem. Como o próprio Marques apresentará no subitem que encerra seu capítulo sobre a Aporía: "Combate de gigantes" (p. 187). Nesse caso, o entrelaçamento das categorias de movimento, repouso, mesmo e outro está totalmente ligada ao entrelaçamento entre ser e não-ser que acontece na imagem.

Nesse sentido, além do estranhamento em relação à terceira margem do rio, essa terceira margem também concilia movimento e repouso, permanência e mudança, identidade e diferença, que serão tematizados no diálogo platônico através dos quatro grandes gêneros: mesmo, outro, movimento e repouso. Além disso, essa relação com o pai

\footnotetext{
metafóricas mantidas pela disseminação de seus componentes” (BURGOS, Ribeira metafísica nos contos de Guimarães Rosa, p. 5).

${ }^{35}$ ROSA, A terceira margem do rio, p. 77

${ }^{36}$ Idem, p. 78 , grifo nosso

37 Para as leituras transcendentes, ver ARAÚJO, A poética moderna em "A terceira margem do rio", de João Guimarães Rosa e ALBERT, A Finitude e transcendência em "A terceira margem do rio". Para uma leitura que mistura Bachelard e misticismo triádico, ver BUHLER, As margens do devaneio: uma análise do conto "A terceira margem do rio", de João Guimarães Rosa.

${ }^{38}$ ROSA, A terceira margem do rio, p. 81
} 
está conectada à questão do parricídio no Sofista, que ocorre porque é preciso romper não somente com os sofistas, mas com a via impedida por Parmênides, que negava a possibilidade do ser não-ser.

\title{
3 Conclusão
}

Como foi dito acima, Marques procura esclarecer como a imagem é o centro da discussão sobre a linguagem, na medida em que ambas não se reduzem ao mundo que retratam e estruturam-se sob o mesmo tipo de alteridade. Ao concentrar-se na relação entre imagem e o ser de um não-ser, o diálogo procura fundar a própria linguagem como outro e para isso toma os sofistas como alvo sem ignorar que ao dar ser ao não-ser será preciso também revisar o pai Parmênides. Em outros termos, só tem sentido discutir a alteridade no Sofista se essa discussão for fundada na ontologia da imagem, pois a ontologia do falso depende também da possibilidade de saber se ele é algo, e se ele é algo, o que ele é, e se falar nele não implica em contradições que possam destruir a linguagem.

E assim o mestre Marques descreve o papel da imagem:

\begin{abstract}
A solução última do filósofo, no Sofista, consistirá em mostrar que essas relações devem ser reguladas ontologicamente pelo entrelaçamento do não-ser ao ser, tornado possível pela forma do outro. Ora, a imagem é este ser que reúne em seu modo de ser justamente os elementos necessários para formular o problema do discurso falso e da contradição: o discurso falso é algo que não é justamente aquilo que pretende ser. A imagem é esta aparência de contradição tornada tangível. Para que o Estrangeiro possa estabelecer o discurso falso, é necessário que compreenda a imagem, que mostre que ela é e que ela só é contraditória em aparência, que o discurso é possível enquanto uma de suas espécies e que ele só é falso quando confunde o que é mesmo com o que é outro ${ }^{39}$.
\end{abstract}

A possibilidade dessa investigação sobre o falso é devedora da ontologia das imagens, na medida em que também se investiga se ela é algo e o que ela é. Do contrário, se não for levada em conta a imagem, nem a produção de imagens em uma resposta sobre o problema do falso, isso implica que a resposta para o paradoxo do falso estará incompleta ou insuficiente por se esquecer de mostrar e provar a centralidade da discussão sobre imagens ${ }^{40}$.

E para ilustrar isso Marques recorre a trechos da literatura que se debruçam sobre essa espécie de alteridade indissolúvel ou essa diferença intransponível e marcadamente atópica da loucura, da miragem, da simultaneidade, do entrelaçamento. Isso se manifesta no caso do saber negativo de Darl presente na sua incapacidade de decidir se ele é ou não é, para dormir, bem como se aproxima da miragem que não é, mas é aos nossos olhos, conectando-se também à simultaneidade do verdadeiro e do falso e se associando à percepção de que o pai está presente e não. Diante do exposto, é possível sustentar que essas epígrafes literárias possuem uma relação direta com a temática abordada no Sofista e foram escolhidas com precisão por Marques por também estarem nesse mesmo conflito fundador da linguagem filosófico-literária ao se depararem com a possibilidade de atribuir algum ser àquilo que não é. Essa escolha é precisa porque funciona como uma abertura para a

\footnotetext{
${ }^{39}$ MARQUES, Platão, pensador da diferença, p. 172

${ }^{40}$ Outros comentadores também podem ser utilizados aqui para provar que a imagem é a resposta que Platão fornece ao problema do falso. Como destaca Ambuel, a contradição inerente à imagem aparece porque ele se estrutura em ser aquilo que não é a coisa mesma, dar um certo ser ao não-ser. Em outro momento, Ambuel também sustenta que se não houver falsidade, não haverá imagens ou vice-versa (AMBUEL, Image and Paradigm in Plato's Sophist, p. xvi).
} 
imaginação de seus leitores, uma espécie de abertura de certa forma limitada e recortada através da qual é possível deixar a imaginação transbordar para além do diálogo Sofista e para além do próprio comentário ao Sofista. Nesse sentido, o horizonte é também dialético porque confronta nomes, definições e impressões.

É óbvio que essa reconstrução proposta aqui não pode e nem deve ser vista como se fosse reveladora da intenção do autor, porque afinal de contas, qual interpretação Marques vislumbra de Darl, da miragem, da simultaneidade, da terceira margem? Ele nunca respondeu a essas perguntas quando estava vivo, ele mesmo não as interpreta, só aponta. Esse texto foi uma tentativa de abrir-se ao silêncio provocado pela morte de todo autor, logo que escreve seu texto e o dirige ao mundo. Jamais poderíamos ter a esperança de revelar aqui qual foi a intenção de Marques ao utilizar essas epígrafes, no bom espírito gadameriano que ele assumia sutilmente com frequência em relação ao próprio Platão. Esse artigo está repleto de interpretações possíveis do modo como eu vejo o Sofista através das lentes literárias que Marques colocou no texto, mas para se concordar com isso é preciso adotar um pouco o mesmo grau ou foco dessas lentes que eu aqui projetei ou colocar mais espelhos nesse caleidoscópio de alteridades continuando o que está sendo defendido aqui.

"O livro [ou nesse caso o artigo] pode valer pelo muito que nele não deve caber"

\section{Referências}

ALBERT, A Finitude e transcendência em "A terceira margem do rio". Contexto, n. 10, 2003, pp. 84-91.

AMBUEL, D. Image and Paradigm in Plato's Sophist. Las Vegas/Zurich/ Athens: Parmenides Publishing, 2007.

ARAÚJO, B. A poética moderna em A terceira margem do rio, de João Guimarães Rosa, RevLet - Revista Virtual de Letras, v. o8, n. 2, ago/dez, 2016, pp. 364-376.

BARROS, L., BRITO, L. Darl, o homem de gênio em Faulkner, A Palo Seco, ano 7, n. 7, 2015, pp. 9-20.

BONDENSON, W. “Sophist: falsehoods and images”. Apeiron, v. 6, n. 2, 1972, pp. 1-6.

BUHLER, A. As margens do devaneio: uma análise do conto “A terceira margem do rio”, de João Guimarães Rosa, Graphos, João Pessoa, v. 8, n. 1, Jan./Jul., 2006, p. 59-62.

BURGOS, F. Ribeira metafísica nos contos de Guimarães Rosa. Disponível em www.brasa.org/wordpress/Documents/BRASA IX/Fernando-Burgos.pdf, Acessado em: $15 / 07 / 2017$.

CRIVELLI, P. Plato's Account of Falsehood: a study of the Sophist. New York: Cambridge University Press, 2012.

DESCLOS, M.-L. Idoles, icônes et phantasmes dans les dialogues de Platon. Revue de Métaphysique et de Morale, 3, 2000, pp.301-322.

\footnotetext{
${ }^{41}$ ROSA, Tutaméia, citado por Marcelo Pimenta Marques, como epígrafe final de seu livro Platão, pensador da diferença.
} 
FAULKNER, W. Enquanto Agonizo. Trad. Hélio Pólvora. Rio de Janeiro: Expansão Editorial, 1978.

GADAMER, H.-G. Verdade e Método. Trad. Flávio P. Meurer. Vol. I. Rio de Janeiro: Vozes, 1999.

KAHN, C. Plato and the post-socratic dialogue: the return to the philosophy of nature. Cambridge: Cambridge University Press, 2016.

MARQUES, M. Platão, pensador da diferença - Uma leitura do Sofista. Belo Horizonte: EDUFMG, 2006.

MARQUES, M. P. O caminho poético de Parmênides. São Paulo: Loyola, 1991.

MARQUES, M. P. “La phantasia chez Platon”. In: VEGLERIS (ed.) Cosmos et psyche. Hildescheim: Georg Olms Verlag, 2005, pp. 123-141.

MARQUES, M. P. Phantasía em Platão. Tópicos, Cidade do México 28, 2005, pp. 57-82.

MARQUES, M. P. "Mímesis no Sofista de Platão”. In: DUARTE, R.; FIGUEIREDO, V. Mímeses e Expressão. Belo Horizonte: Ed. UFMG, 2001, pp. 169-173.

MARQUES, M. P. (Org.) Teorias da imagem na Antiguidade. São Paulo: Paulus, 2012.

MELO, J. A questão da ambivalência em “A terceira margem do rio”. Revista do CESP, v. 22, n. 30, jan.-jun., 2002, pp. 111-124.

MESTI, D. N. Por uma diferenciação das imagens na República de Platão. Belo Horizonte, Editora UEMG, 2017.

NOTOMI, N. The unity of Plato's Sophist: Between the Sophist and the Philosopher. Cambridge: Cambridge University Press, 1999.

PLATON. Le Sophiste. Trad. Nestor L. Cordero. Paris: GFlamarion, 1993.

PLATÃO. Diálogos: Fedro, Cartas, Primeiro Alcebíades. Trad. Carlos Alberto Nunes. Belém: EDUFPA, 1975.

PALMER, J. Plato's Reception of Parmenides. Oxford: Clarendon Press, 1999.

ROSA, J. G. A terceira margem do rio. In: Primeiras estórias. Rio de Janeiro: Nova Fronteira, 2005, pp. 77-82.

ROSEN, S. Plato's Sophist: The Drama of Original \& Image. Indiana: St. Augustine's Press, 1999.

TEISSERENC, F. Remarques sur l' imitation et le statut ontologique de l' image chez Platon. Cahier de Philosophie de Strasbourg, 3, 1995, pp. 149-164.

VERNANT, J.-P. Image et apparence dans la théorie platonicienne de la mimesis. JPNP 62, 1975, pp. 133-16o. 